\title{
Missionaries and Indigenous Education in the 19th- Century British Empire. Part I: Church-State Relations and Indigenous Actions and Reactions
}

Felicity Jensz*

Cluster of Excellence for Religion and Politics, Westfälische Wilhelms-Universität Münster

\begin{abstract}
Missionaries were major providers of education in the colonial world, and in many cases were the initial and exclusive agents of education for Indigenous and non-European people, whom they hoped could be converted to Christianity through religious schooling. However, by the end of the 19th century many governments in colonial lands were keen to take more active roles in providing secular education for their subjects, which, in turn, engendered tensions between missionary groups, governments, and the Indigenous communities for whom education was provided. Although the article of missions has received increasing attention in the last few decades, especially with the advent of postcolonial studies, there are still many aspects of missionary schooling that are understudied. This research overview examines the debates and research directions which are evident in the article of missionaries and their education of Indigenous and non-European peoples in the 19th century, and focuses particularly upon major themes emerging from the literature: Two of these themes-Church-State relations and Indigenous action and reaction will be examined in this article, whilst the themes of race, class, and gender will be examined in the second part.
\end{abstract}

Once sidelined to religious or church history, since the publication of John and Jean Comaroff's 1991 and 1997 'Of Revelation and Revolution', ${ }^{1}$ missionaries have increasingly become under the attention of many different areas of scholarship. ${ }^{2}$ They were the focus of a volume in the companion series of the 'Oxford History of the British Empire' $(\mathrm{OHBE})$. Yet, as the editor of this volume Norman Etherington suggests, its publication was also an indication of the initial oversight of the missionary endeavor in the original series. ${ }^{3}$ The Comaroffs are working on a third volume in their 'Of Revelation and Revolution' series that will be dedicated to colonial pedagogy. ${ }^{4}$ In light of the interest that this volume will likely raise in the role of missionary education and its role in colonialism, modernity, and identity construction, it is apt to examine the debates and research directions which are evident in the article of missionaries and their education of Indigenous and non-European peoples in the 19th century, beyond the geographical area of sub-Saharan Africa in which the Comaroffs specialize, and the geographical area within which in 1938 it was estimated that nine-tenths of education was administered by missionary societies. ${ }^{5}$ Missionaries were major providers of education in the colonial world, and in many cases were the initial and exclusive agents of education for Indigenous and non-European peoples in the English speaking (post-)colonial world. ${ }^{6}$ However, by the end of the 19th century many governments in colonial and postcolonial lands were keen to take more active roles in providing education for their subjects, which, in turn, engendered tensions between missionary groups, governments, and the Indigenous communities for whom education was provided. 
Despite the crucial role that education and schooling played in missionary work in the 19th century, the educational aspect of missionaries' work has received less specific attention than broader aspects such as cultural contact, or the construction of the Western self. Although work on education on mission stations has received attention from many different areas of scholarship, scholars of the history of education have been at the forefront of examining missionary education, often in transnational and postcolonial perspectives. ${ }^{7}$ The history of education has traditionally been seen to be on the borders of two academic disciplines, ${ }^{8}$ with post-colonial theories providing a bridge between the areas of colonial history and education. ${ }^{9}$ Within both missionary and colonial studies, post-colonial theory has also shaped much of the scholarship over the last couple of decades. However, missionary education has not received much scholarly attention from colonial historians, despite the fact that, as António Nóvoa notes, education was, and remains, a major contributor to the construction of the 'other'. ${ }^{10}$

In drawing together various fields of research for this article, a number of interlaced themes emerge, with Church-State relations and native action and reaction being examined in this article and race, class and gender examined in a subsequent article. The broad brush strokes dictated by this overview necessitate generalizations and omissions. For example, just as the Indigenous peoples amongst whom missionaries worked cannot be homogenized into a singular 'other', neither is there a single category of 'missionary'. There were not only confessional differences between Catholic and Protestant missionary organizations, but also denominational differences between Protestant societies, as well as differences between Catholic groups, all of which influenced how schooling was both presented and received. ${ }^{11}$ Many missionaries working in the English-speaking world were not British, rather continental European Protestants or Catholics. Such culturally varied backgrounds obviously had ramifications. However, because not much has been undertaken by way of comparative missionary education-rather most studies have been geographically specific - the encapsulation of a broad variety of missionary groups and a vast geographical area seems particularly desirable. ${ }^{12}$ Neither this nor the subsequent article aim to contribute to arguments on the effects of missionary education, nor to devise a universal narrative (although broad generalizations will be made), rather they aim to survey the historiography of missionary education to Indigenous and non-European peoples in the British Empire of the 19th century and to point out major themes of research, as well as gaps in scholarship, all the while building an image of the commonalities of missionary education over the vast geographical and temporal scale of the British Empire during the long 19th century.

Christian missionaries aimed to educate Indigenous people through non-institutional forms such as acting as suitable 'role-models', one-on-one instructional conversations, friendly persuasion, the giving or withholding of gifts and/or rations, and encouraging perceived appropriate or discouraging perceived inappropriate behavior. There was also great variation in forms of institutionalized schooling offered by missionaries: from infant schools; to day schools; to secondary schools and colleges; to universities and seminaries. Some denominations offered only practical elementary education, others offered both primary and secondary, other groups offered classical education to their converts, and some missionary groups offered teacher-training to non-Europeans in order that more missionary schools could be supplied with teachers. Often missionary teachers themselves had no formal training and improvised in situ. The role of a missionary was an educational one on many fronts, for not only was it expected that missionaries would establish formal educational institutions for non-Europeans, they were also expected to inform and teach their support audiences at home as to the benefits of missionary work. Although scholars 
such as Hayden Bellenoit posit a broad understanding of education to encompass all forms of "religious, spiritual and anthropological experiences", 13 within this paper, the term will be limited to institutionalized schooling, with a particular focus on the schooling of youth. ${ }^{14}$

\section{Missionary Organizations' Relationships with Colonial Governments}

The establishment of mission schools for Indigenous peoples was one way in which the Christian presence was institutionalized within the colonies. ${ }^{15}$ Such schools were a natural extension of the traditional work of religious organizations in providing education to both the elite and the masses in Britain. In the majority of colonies, education was promoted by governments with a major goal being the creation of Indigenous and local workers who were expected to contribute to the colonial apparatus. Exceptions to this were the settler colonies, in which Indigenous people were not seen to be essential to the continuation of the colony. Much more apparent in these colonies was the governments' desire to assimilate Indigenous peoples, for which education was a vital tool, and in turn to reduce spending on Indigenous affairs. ${ }^{16}$ Aside from the labor outcomes and financial benefits of educating local communities, the British government also deemed the provision of religious education to Indigenous peoples in their colonies as a moral obligation, with the 1837 British Parliamentary Select committee on Aboriginal Tribes suggesting that Indigenous peoples in the colonies should be protected from the negative effects of civilization, preferably through the benevolent efforts of Christian missionaries, who were to provide religious instruction and education embedded with Christian norms and morals. ${ }^{17}$ In the 19 th century, missionaries and British colonial governments were thus unified in their desire to provide schooling to non-European peoples, however, whereas the focus for missionaries was often primarily upon the religious aspects of education, the British government's objectives were to educate a section of colonial society to become good subjects of that society.

Missionary organizations relied upon governmental support to provide them grants of land, permission to establish missions in colonies, and government funding for schools and supplies. When these were withheld or withdrawn, missionary organizations either discontinued their missions or needed to find other forms of support. Governments relied upon missionary organizations to subsidize the costs of providing education, and missionary societies themselves often relied upon the financial support of governments to help cover the expense of education on mission stations. However, as Norman Etherington has noted, government funding of missionary schools was often a "poisoned chalice," for the more money governments gave, the more they wished to determine the methods and curriculums of these schools, as well as their desired outcomes. ${ }^{18}$ Often this resulted in a curriculum which was focused upon rudimentary vocational training, which, in turn, severely limited educational opportunities for Indigenous people. For the missionaries, government intervention was particularly undesirable when it compromised the religious content of the curriculum, for this undermined the position of missionary education, and thus of missionary societies themselves. Throughout the 19th century, colonial governments changed their policies towards indigenous inhabitants and the role of native education, and when this happened missionaries needed to find ways to respond and adapt to different governmental positions.

Although the colonial authorities around the British world commonly supported religious organizations in their establishment and maintenance of schools with religious and moral instruction, ${ }^{19}$ there was no uniformity in British colonial educational policy, ${ }^{20}$ with 
many colonial governments allowing local conditions to dictate need and relying upon missionary bodies to provide the education that they themselves could not initially provide. ${ }^{21}$ Throughout the British Empire by the end of the 19th century, colonial education had become more institutionalized, with government policy becoming more unified both within and between colonies. ${ }^{22}$ The institutionalization of colonial education was exemplified in the establishment of departments of education around the turn of the century, ${ }^{23}$ and, as a consequence, missionaries often lost their privileged positions as providers of Western education. As Sue Krige has argued, missionaries in South Africa reacted to this governmental shift by positioning themselves as experts in Indigenous education, ${ }^{24}$ with an analogous positioning of missionaries as expert advisors to the government occurring in Canada in the 1870s. ${ }^{25}$ In other colonial spaces such as the Pacific, where external pressures on Indigenous education were not so evident, the symbiotic relationship between Church and State in terms of missionary education continued well into the 20th century. $^{26}$

Through initially allowing missionaries to be the major providers of schooling, and thus to be closer to the causes and effects of religious and cultural changes, governments were able to deflect local criticism of direct interference in Indigenous religion and culture, and were thus able to circumvent local rebellious tendencies. ${ }^{27}$ By the end of the 19th century, many colonial governments saw missionary education to be outdated and instead advocated for modern, scientific and secular forms of education, implementing a more marked division between religious and secular subjects. ${ }^{28}$ However, as Sanjay Seth has postulated in his article of colonial education in India, modern knowledge is not analogous with modernity, ${ }^{29}$ a verity with which many missionary societies agreed, as they themselves were critical of, and distanced themselves from, many manifestations of modernity. ${ }^{30}$ Despite such concerns, the entangled nature of the colonial educational project ensured that missionary organizations were reliant on and coexistent with government policy. Especially in the latter part of the century when universal education increasingly became a colonial governmental concern, missionaries themselves became agents of the state in their roles as paid governmental teachers or colonial school inspectors, demonstrating the entwined relationship between religion and politics in the colonies. Exactly how missionaries and their Indigenous scholars responded to such dual roles has yet to be extensively researched.

\section{Indigenous Action and Reaction}

Before the arrival of missionaries, Indigenous peoples had their own forms of education, both informal and formal. These were, however, often overlooked by missionaries as Indigenous educational methods did not conform to Western expectations of schooling. ${ }^{31}$ In many locations formal schooling, such as Madāis or Buddhist schools, had existed prior to the arrival of Christian missionaries, and such schools were seen by many missionaries as both a hindrance and competitor to their desire to spread the Christian message, as well as an indication that Indigenous peoples were 'sophisticated' enough to appreciate formal Western education. ${ }^{32}$ Yet, as Philip Constable has noted in the context of India, missionaries were forced to refocus their educational and missionary targets when they failed to convert members of the Hindu elite castes, leading to a shift from elite education to mass vernacular education and missionary work. ${ }^{33}$ Indigenous peoples also shifted their allegiances away from missionaries when schooling did not fit their desires, either through changing denominations or confessions-creating rivalries between religious groups ${ }^{34}$ - or even establishing their own schools with their own native teachers. ${ }^{35}$ 
Although Indigenous peoples took over the bulk of the proselytizing after an initial period of missionizing, teaching work remained under the control of European missionaries. $^{36}$ Native missionary teachers, although subordinate to their Western counterparts, were sought both to relieve the financial and time burden for Western missionaries, as well as to provide good role models for other Indigenous people. Indigenous people who were trained to become teachers and lay-preachers gained heightened positions in the mission hierarchy, ensuring their vested interests in such work. Missionaries saw their schools as nurseries of the Church. Young children and youth were the main targets, as through enticing them missionary groups hoped both to cultivate life-long loyal supporters as well as to gain access to these childrens' parents, and ultimately also to convert them to Christianity. ${ }^{37}$ However, although many Indigenous groups desired Western education, they were often skeptical of the Christian message and boycotted overly proselytizing institutions. ${ }^{38}$ Unlike schools in England, where from 1870 attendance was compulsory and fees were mandatory, ${ }^{39}$ missionaries in the colonies had to find various ways, depending on the context, both to encourage children to attend schools, and to gain the consent of their parents and communities. Some missionaries, such as the French Catholic White Fathers in Zambia, offered children a penny a day to attend school, with the hope of obtaining regular attendance. ${ }^{40}$ In India, CMS missionaries paid girls to attend school, as well as provided them with free accommodation and servants. ${ }^{41}$ Scottish Protestant missionaries in Eastern Nigeria rewarded the success of their pupils through gifts of clothing. ${ }^{42}$ Children and youth were willing to brace the wrath of their parents to attend missionary schools, ${ }^{43}$ demonstrating that attendance at, or resistance to, missionary schooling was not always a homogenous group decision.

Far from being seen as only a product of Western imperial designs, missionary educational work relied upon the cooperation of local elites and also the willingness of parents to send their children to mission schools. ${ }^{44}$ As Robert Strayer observed almost 40 years ago, "Africans were by no means passive recipients of European education and further ... their attitudes and actions sometimes played an important role in shaping the educational policies and institutions of the colonial world." 45 Strayer further heeds us to acknowledge the influence that Indigenous parents and communities had on the development and evolution of schooling, noting that the term 'missionary schooling' is a misnomer if it indicates only the agency of missionaries in the provision of education. ${ }^{46}$ In the 1970s, Barbra Yates suggested that there were three discernible stages of African reaction to schooling: "indifference; curiosity; and finally widespread acceptance." 47 In this last stage, many Indigenous and non-European peoples both demanded and embraced missionary education in their ambitious desires for their children, with education being an increasingly desired commodity leading up to and after the abolition of slavery in places such as Africa and the West Indies. ${ }^{48}$ In his 1974 work on African responses to missionary schooling, Edward Berman nominated three categories of intentions behind engaging in missionary schooling: political; economic; and social-psychological. ${ }^{49}$ Although Yates' categories could be extended to include both Indigenous passive and active resistance as well as Indigenous engagement in missionary education, ${ }^{50}$ and Berman's categories could be broadened to include religious intentions, both basic categorizations remain useful especially when taking into account, as Berman noted, that such categories were not mutually exclusive, and were heavily influenced by changing external stimuli. Missionary schooling was seen by many Indigenous peoples as a means to increase economic and political status - through, for example, a job in the colonial government - and thus as a benefit of Western colonization. ${ }^{51}$ Moreover, it also contributed to later nationalist politics. $^{52}$ This is not, however, to say that all Indigenous peoples accepted the content or 
form of missionary schooling wholesale, or that the skills learnt through schooling were not put to uses that the missionaries themselves may have not envisaged, or approved of. ${ }^{53}$ There is much further work to be undertaken in this area, however it is often hindered by the one-sided nature of missionary sources. ${ }^{54}$

\section{Conclusion}

Through examining these two aspects of missionary education, that being Church-State relations and Indigenous actions and reactions, it is evident that the role of missionaries in Indigenous education is ambiguous and often contradictory, with contemporaneous observers and well as recent scholars often divided over how to evaluate the aims and results of missionary education. Some scholars view missionary education as proof of missionaries' humanitarian, as opposed to imperialist, nature, ${ }^{55}$ with others focus upon the detrimental nature of missionary education in terms of cultural destruction and cultural hegemony. ${ }^{56}$ Missionary work in the colonies, including their educational work, has been deemed "cultural imperialism", and often seen as an inextricable aspect of European empire building. ${ }^{57}$ Yet since the 1990s the historiography has decidedly moved from this position to a more nuanced understanding of the relationship between missionaries and colonial governments, through documenting the dynamic negotiations of different relationships in different types of colonies and at different times. ${ }^{58}$ The growth of academic interest in missionary endeavors beyond church history has also coincided with, as well as been a product of, a shift towards using post-colonial methodologies, evident in the increased scholarly focus on "local agents of Christian expansion", which, in turn, placed into question previously held notions of the roles of missionaries in the colonial encounter. ${ }^{59}$ The shifts in missionary historiography affect our understanding of the educational work of missionaries, for missionary education was not monolithic, rather it played itself out differently as the various colonies and protectorates dynamically responded to local environments, including both those offered by colonial and local governments as well as Indigenous peoples. Through a broad view of missionary education over various colonies, this article also indicates the importance of focusing upon some of the commonalities of missionary education in order to obtain a better understanding of the transnational and dynamic focus of missionary work. Overwhelmingly it was missionaries who initially provided Indigenous peoples with Western education, with the formation of later colonial educational systems often built upon missionary structures. Understanding both the commonalities and differences across different locations provides us with a clearer insights into how diverse educational outcomes for missionary school pupils were articulated and enacted, and how the relationship between missionaries, Indigenous peoples, and governments affected these outcomes.

\section{Short Biography}

Felicity Jensz's research focuses upon the relationships between missionaries, Indigenous peoples, and governments in the 19th-century British colonial world, with a particularly focus on the transnational aspects of these relationships. She has a particular interest in German-speaking Moravian missionaries and has published papers on this group in Aboriginal History, Journal of the History of Collections, and Journal of Religious History. Her book Moravian Missionaries in the British Colony of Victoria, Australia (Brill, 2010) examined the complex tensions between non-British missionaries and British colonial governance. Current research focuses upon missionary education as well as missionary periodicals in the 
19th century. She is a Postdoctoral Research Fellow in the Cluster of Excellence for Religion and Politics at the Westfälische Wilhelms-Universität Münster, Germany and an Honorary Fellow in the School of Historical Studies at the University of Melbourne, Australia, where she obtained her Ph.D.

\begin{abstract}
Notes
* Correspondence: Cluster of Excellence for Religion and Politics, Westfälische Wilhelms-Universität Münster, Johannisstr. 1-4, 48143 Münster, Germany. Email: felicity.jensz@uni-muenster.de.
\end{abstract}

1 Jean Comaroff and John Comaroff, Of Revelation and Revolution: Christianity, Colonialism, and Consciousness in South Africa, vol. 1 (Chicago and London: The University of Chicago Press, 1991); John Comaroff and Jean Comaroff, Of Revelation and Revolution: The Dialetics of Modernity on a South African Frontier, vol. 2 (Chicago: The University of Chicago Press, 1997). For an overview on the debate which the Comeroff's book ignited amongst historians see: Elizabeth Elbourne, 'Word Made Flesh: Christianity, Modernity, and Cultural Colonialism in the Work of Jean and John Comaroff, The American Historical Review, 108/2 (2003): 435-59.

2 For an overview of the historiography of missionary history see: Norman Etherington, 'Missions and Empire', in R. Winks (ed.), Oxford History of the British Empire, Volume 5: Historiography, (Oxford: Oxford University Press, 1999), 303-14; Patricia Grimshaw and Andrew May, 'Reappraisals of Mission History: An Introduction', in Patricia Grimshaw and Andrew May (eds.), Missionaries, Indigenous Peoples and Cultural Exchange, First Nations and the Colonial Encounter, (Brighton, Portland, Toronto: Sussex Academic Press, 2010), 1-9.

3 Norman Etherington, 'Introduction', in Norman Etherington (ed.), Missions and Empire. The Oxford History of the British Empire Companion Series, (Oxford and New York: Oxford University Press, 2005), 1.

4 Comaroff and Comaroff, Of Revelation and Revolution, vol 2. xvi.

5 Norman Etherington, 'Education and Medicine', in Norman Etherington (ed.), Missions and Empire. The Oxford History of the British Empire Companion Series, (Oxford and New York: Oxford University Press, 2005$), 273$.

6 See for example: Brendan Carmody, 'Catholic Schools in Zambia: 1891-1924', History of Education, 28/1 (1999): 73; Rashida Keshavjee, 'The Elusive Access to Education for Muslim Women in Kenya from the Late Nineteenth Century to the "Winds of Change" in Africa (1890s to 1960s)', Paedagogica Historica, 46/1\&2 (2010): 103.

7 See for example: Joyce Goodman, Gary McCulloch, and William Richardson, "Empires Overseas" and "Empires at Home": Postcolonial and Transnational Perspectives on Social Change in the History of Education', Paedagogica Historica, 45/6 (2009): 695-706; A. Nóvoa, M. Depaepe and E.V. Johanningmeier, (eds.), The Colonial Experience in Education: Historical Issues and Perspectives. Paedagogica Historica Supplementary Series, vol. 1 (Ghent: C.H.S.P., 1995).

8 António Nóvoa, 'On History, History of Education, and History of Colonial Education', Paedagogica Historica, Supplementary Series, vol. 1 (1995), 33.

9 Antonio Novoa, 'Empires Overseas and Empires at Home', Paedagogica Historica, 45/6 (2009), 820.

10 Novoa, 'Empires Overseas and Empires at Home', 820.

11 For example see: E. A. Ayandele, The Missionary Impact on Modern Nigeria 1842-1914. A Political and Social Analysis (London: Longman, 1966), 49.

12 Exceptions to this are Brian Holmes' edited volume on 'Educational Policy and the Mission Schools' (1967, reprinted in 2007) and the works of Norman Etherington, Clayton Mackenzie, and Clive Whitehead; all of which take a British Empire, or broader global, approach. Whitehead, however, does not engage with new scholarship on the role of missionary education in the colonies, as seen by the paucity of secondary sources from the 1990s or 2000s in his texts. See: Brian Holmes (ed.), Educational Policy and the Mission Schools. Case Studies from the British Empire, 2nd edn., (London: Routledge \& Kegan Paul, 2007).; Larry Prochner, Helen May, and Baljit Kaur, “"The Blessings of Civilisation": Nineteenth-Century Missionary Infant Schools for Young Native Children in Three Colonial Settings - India, Canada and New Zealand 1820s-1840s', Paedagogica Historica, 45/1\&2 (2009): 83-102; Etherington, 'Education and Medicine'; Clayton G. Mackenzie, 'Demythologising the Missionaries: A Reassessment of the Functions and Relationships of Christian Missionary Education under Colonialism', Comparative Education, $29 / 1$ (1993): 45-66.; Clive Whitehead, 'Education in British Colonial Dependencies, 1919-39: A Re-Appraisal'. Comparative Education, 17/1 (1981): 71-80; Clive Whitehead, 'The Historiography of British Imperial Education Policy, Part I: India', History of Education, 34/3 (2005): 315-29.; Clive Whitehead, 'The Concept of British Education Policy in the Colonies 1850-1960,' Journal of Educational Administration \& History, 39/2 (2007): 161-73.

13 Hayden J. A. Bellenoit, Missionary Education and Empire in Late Colonial India, 1860-1920 (London: Pickering \& Chatto, 2007), 11.

14 Other forms of Western missionary schooling, such as the education of non-Europeans missionary converts in Europe, are excluded from this analysis. So too, is the education of the home audience through missionary propaganda. The presence of non-Europeans at missionary educational facilities in Europe is a topic of relatively little 
research. See a brief overview see: Christian Stuart Davies, “'Coddling” African Abroad: Colonial Director Paul Kayser and the Education of Africans in Germany, 1891-1896', Journal of Colonialism and Colonial History, 9/1 (2008) (E-ISSN: 1532-5768, accessed via Project Muse, July 1, 2011).

15 See for example: Jeffrey Cox, Imperial Fault Lines: Christianity and Colonial Power in India, 1818-1940 (Stanford, CA: Stanford University Press, 2002).

16 See for example: Julie Evans, Patricia Grimshaw, David Phillips, and Shurlee Swain (eds.), Equal Subjects, Unequal Rights: Indigenous Peoples in British Settler Colonies, 1830-1910, (Manchester: Manchester University Press, 2003), passim.

17 The Report of the Parliamentary Select Committee of Aboriginal Tribes had come quickly after the success of the abolition movement in Britain with many of the same people, such as the humanitarian Sir Thomas Fowell Buxton, involved in the report. Many settlers vocally opposed the report, with economic motives overshadowing the humanitarian ideology that that report had been based on. See: Elizabeth Elbourne, 'The Sin of the Settler: The 1835-36 Select Committee on Aborigines and Debates over Virtue and Conquest in the Early NineteenthCentury British White Settler Empire', Journal of Colonialism and Colonial History, 4/3 (2003) (E-ISSN: 1532-5768, accessed via Project Muse, October 31, 2011).

18 Norman Etherington, 'Missionaries, Africans and the State in the Development of Education in Colonial Natal, 1836-1910,' in Patricia Grimshaw and Andrew May (eds.), Missionaries, Indigenous Peoples and Cultural Exchange, (Brighton, Portland, Toronto: Sussex Academic Press, 2010), 133.

19 Whitehead, 'The Concept of British Education Policy in the Colonies 1850-1960', 164.

20 In the African context see: George E. Urch, 'Education and Colonialism in Kenya', History of Education Quarterly, 11/3 (1971): 249. See also: Whitehead, 'The Concept of British Education Policy in the Colonies 18501960 ', 164.

21 See for example: Tim Allender, 'Anglican Evangelism in North India and the Punjabi Missionary Classroom: The Failure to Educate the "Masses", 1860-77', History of Education, 32/3 (2003): 278.

22 For an African example see: Whitehead, 'The Historiography of British Imperial Education Policy, Part I: India', 441.

23 Ana Isabel Madeira, 'Portuguese, French and British Discourses on Colonial Education: Church \& State Relations, School Expansion and Missionary Competition in Africa, 1890-1930', Paedagogica Historica, 41/1\&2 (2005): 40 .

${ }^{24}$ Sue Krige, “"Trustees and Agents of the State”? Missions and the Formation of Policy Towards African Education, 1910-1920', South African Historical Journal, 40 (1999): 81.

25 In Canada, missionaries positioned themselves as experts in First Nation education and worked closely with the government in devising and realising the residential school policy and practice. See: John Webster Grant, Moon of Wintertime. Missionaries and the Indians of Canada in Encounter since 1534 (Toronto, Buffalo \& London: University of Toronto Press, 1984), 176-83.

26 See for example: Karen Ann Watson-Gegeo and David Welchman Gegeo, 'Schooling, Knowledge, and Power: Social Transformation in the Solomon Islands', Anthropology E Education Quarterly 23/1 (1992): 15-6.

27 See for example: Robert Eric Frykenberg, 'Modern Education in South India, 1784-1854: Its Roots and Its Role as a Vehicle of Integration under Company Raj’, The American Historical Review, 91/1 (1986): 63. Tim Allender posits the opposite when he suggests that governments thought that missionary activity in Punjab, India during the mid-19th century would "made Western education appear more of an artificial imposition." See: Tim Allender, Ruling through Education. The Politics of Schooling in the Colonial Punjab (USA, UK, India: New Dawn Press, 2006), 187.

28 For examples in Africa see: Carmody, 'Catholic Schools in Zambia: 1891-1924', 73; Krige, “"Trustees and Agents of the State'?', 80.

29 Sanjay Seth, Subject Lessons. The Western Education of Colonial India (Durham and London: Duke University Press, 2007), 195.

30 See for example: Gunther Pakendorf, 'A Brief History of the Berlin Mission Society in South Africa', History Compass, 9/2 (2011): 107.

31 For examples in Canada see: James R. Miller, Shingwank's Vision: A History of Native Residential Schools (Toronto: University of Toronto Press, 2009), especially chapter 1. For examples in Africa see: Richard A. Corby, 'Educating Africans for Inferiority under British Rule: Bo School in Sierra Leone', Comparative Education Review, 34/3 (1990): 314-49; Seppo Sivonen, White-Collar or Hoe Handle? African Education under British Colonial Policy 1920-1945 (Helsinki: Suomen Historiallinen Seura, 1995), 43-4.

32 See for example: Keshavjee, 'The Elusive Access to Education for Muslim Women in Kenya from the Late Nineteenth Century to the "Winds of Change" in Africa (1890s to 1960s)', 103-4; Robert W. Strayer, 'The Making of Mission Schools in Kenya: A Microcosmic Perspective', Comparative Education Review, 17/3 (1973): 316.

33 Philip Constable, 'Scottish Missionaries, "Protestant Hinduism" and the Scottish Sense of Empire in Nineteenthand Early Twentieth-Century India', The Scottish Historical Review, 86/2 (2007): 288.

34 See for example: Stephen J. Ball, 'Imperialism, Social Control and the Colonial Curriculum in Africa', Journal of Curriculum Studies, 15/3 (1983): 240; Brian Garvey, 'Colonial Schooling and Missionary Evangelism: The Case of 
Roman Catholic Educational Initiatives in North-Eastern Zambia, 1895-1953', History of Education, 23/2 (1994): $198 \& 206$.

35 See for example: Edward H. Berman, 'African Responses to Christian Mission Education', African Studies Review, 17/3 (1974): 530; Terence Ranger, 'African Attempts to Control Education in East and Central Africa 1900-1939', Past \& Present, 32 (1965): 57-85.

36 See: Etherington, 'Education and Medicine,' 261.

37 See for example: Prochner, May, and Kaur, "“The Blessings of Civilisation", 84.

38 Despite the desire for Western education numerous South African groups boycotted missionary education as it was overly-proselytizing, with similar trends evident in India. See: Hayden J.A. Bellenoit, 'Missionary Education, Religion and Knowledge in India, C. 1880-1915', Modern Asian Studies, 41/2 (2007): 372; Ranger, 'African Attempts to Control Education in East and Central Africa 1900-1939', 66.

39 Jane Lewis, 'Parents, Children, School Fees and the London School Board 1870-1890', History of Education, 11/4 (1982): 291.

40 Carmody, 'Catholic Schools in Zambia: 1891-1924', 83.

41 Allender, Ruling through Education, 199.

42 W. H. Taylor, 'Missionary Education in Africa Reconsidered: The Presbyterian Educational Impact in Eastern Nigeria 1846-1974', African Affairs, 83/331 (1984): 194.

43 See for example: Misty L. Bastian, 'Young Converts: Christian Missions, Gender and Youth in Onitsha, Nigeria 1880-1929', Anthropological Quarterly, 73/3 (2000): 149.

44 Mackenzie, 'Demythologising the Missionaries', 50.

45 Strayer, 'The Making of Mission Schools in Kenya', 313.

46 Strayer, 'The Making of Mission Schools in Kenya', 329.

47 Although Yates case article focuses upon the Congo, her conclusions can be explicated to many British colonies. See: Barbara A. Yates, 'African Reactions to Education: The Congolese Case', Comparative Education Review, 15/2 (1971): 158.

48 See for example: Stephen J. Ball, 'Imperialism, Social Control and the Colonial Curriculum in Africa', 237-63; Patricia T. Rooke, 'A Scramble for Souls: The Impact of the Negro Education Grant on Evangelical Missionaries in the British West Indies', History of Education Quarterly, 21/4 (1981): 429-47; Mary Turner, Slaves and Missionaries. The Disintegration of Jamaican Slave Society, 1787-1834 (Urbana, Chicago, London: University of Illinois Press, 1982), 89.

49 Berman, 'African Responses to Christian Mission Education', 528.

50 Passive resistance was evident in actions such as parents keeping their children away from school, with active resistance including such activities as the establishment of Indigenous schools in competition with the missionary schools. Indigenous engagement is evident in the negotiations between Indigenous parents and missionaries as to what should be taught and how it was to be taught. See for example: Ranjit Ruberu, 'Missionary Education in Ceylon', in Brian Holmes (ed.), Educational Policy and the Mission Schools. Case Studies from the British Empire, (London \& New York: Routledge and Kegan Paul, 2007), 82-5; J. Donald Wilson, " "No Blanket to Be Worn in School": The Education of Indians in Nineteenth-Century Ontario', in Jean Barman, Yvonne Hébert, and Don McCaskill (eds.), Indian Education in Canada, (Vancouver: University of British Columbia Press, 1986), 6487.

51 See for example: Allender, 'Anglican Evangelism in North India and the Punjabi Missionary Classroom', 277.

52 See for example: Brian Stanley, The Bible and the Flag. Protestant Missions and British Imperialism in the Nineteenth and Twentieth Centuries (Leicester: Apollos, 1992), especially pages 16-7, 132-4, 141; Woodberry, Robert, 'The Shadow of Empire: Christian Missions, Colonial Policy, and Democracy in Postcolonial Societies', Ph.D. dissertation (University of North Carolina at Chapel Hill, 2004), passim.

53 See for example: Alan Kirkaldy, "“The Missionary Impact": The Northern Transvaal in the Late Nineteenth Century', History Compass, 7/3 (2009): 609; Isabel Hofmeyr, 'Dreams, Documents and “Fetishes”: African Christian Interpretations of "The Pilgrim's Progress", , Journal of Religion in Africa, 32/4 (2002): 449.

54 For a discussion on the limited nature of missionary sources and the manipulation of missionary texts see for example: Lize Kriel, 'From Private Journal to Published Periodical', Book History 11 (2008): 169-98; Doug Munro and Andrew Thornley, 'Pacific Islander Pastors and Missionaries: Some Historiographical and Analytical Issues', Pacific Studies 23/3/4 (2000): 13-8.

55 For a brief overview on the humanitarian versus imperial agent debate in the Australian context see: Anne O'Brien, 'Creating the Aboriginal Pauper: Missionary Ideas in Early 19th Century Australia', Social Sciences \& Missions, 21/1 (2008): 9.

56 See for example discussion in Whitehead: Whitehead, 'The Historiography of British Imperial Education Policy, Part I: India', 444.

57 For an overview see: Ian Copland, 'Christianity as an Arm of Empire: The Ambiguous Case of India under the Company, C. 1813-1858', The Historical Journal, 49/4 (2006):1025-54.

58 The two most influential promoters of a more nuanced reading of the colonial-missionary relationship are Andrew Porter and Brian Stanley. See for example: Stanley, The Bible and the Flag; Andrew Porter, Religion Versus 
Empire? British Protestant Missionaries and Overseas Expansion, 1700-1914 (Manchester: Manchester University Press, 2004).

59 Etherington, 'Missions and Empire', 303-14

\section{Bibliography}

Allender, Tim, 'Anglican Evangelism in North India and the Punjabi Missionary Classroom: The Failure to Educate the 'Masses', 1860-77', History of Education, 32/3 (2003): 273-88.

Allender, Tim, Ruling through Education. The Politics of Schooling in the Colonial Punjab (USA, UK, India: New Dawn Press, 2006).

Ayandele, E. A., The Missionary Impact on Modern Nigeria 1842-1914. A Political and Social Analysis (London: Longman, 1966).

Ball, Stephen J., 'Imperialism, Social Control and the Colonial Curriculum in Africa', Journal of Curriculum Studies, 15/3 (1983): 237-63.

Bastian, Misty L., 'Young Converts: Christian Missions, Gender and Youth in Onitsha, Nigeria 1880-1929', Anthropological Quarterly, 73/3 (2000): 145-58.

Bellenoit, Hayden J.A., 'Missionary Education, Religion and Knowledge in India, C. 1880-1915', Modern Asian Studies, 41/2 (2007): 369-94.

Bellenoit, Hayden J. A., Missionary Education and Empire in Late Colonial India, 1860-1920 (London: Pickering \& Chatto, 2007).

Berman, Edward H., 'African Responses to Christian Mission Education', African Studies Review, 17/3 (1974): 52740.

Carmody, Brendan, 'Catholic Schools in Zambia: 1891-1924', History of Education, 28/1 (1999): 73-86.

Comaroff, John, and Comaroff, Jean, Of Revelation and Revolution: Christianity, Colonism, and Consciousness in South Africa, vol. 1 (Chicago and London: The University of Chicago Press, 1991).

Comaroff, John, and Comaroff, Jean, Of Revelation and Revolution: The Dialetics of Modernity on a South African Frontier, vol. 2 (Chicago: The University of Chicago Press, 1997).

Constable, Philip, 'Scottish Missionaries, "Protestant Hinduism" and the Scottish Sense of Empire in Nineteenthand Early Twentieth-Century India', The Scottish Historical Review, 86/2 (2007): 278-313.

Copland, Ian, 'Christianity as an Arm of Empire: The Ambiguous Case of India under the Company, C. 1813-1858', The Historical Journal, 49/4 (2006): 1025-54.

Corby, Richard A., 'Educating Africans for Inferiority under British Rule: Bo School in Sierra Leone', Comparative Education Review, 34/3 (1990): 314-49.

Cox, Jeffrey, Imperial Fault Lines: Christianity and Colonial Power in India, 1818-1940 (Stanford, Calif.: Stanford University Press, 2002).

Davies, Christian Stuart, " "Coddling” African Abroad: Colonial Director Paul Kayser and the Education of Africans in Germany, 1891-1896', Journal of Colonialism and Colonial History, $9 / 1$ (2008) (E-ISSN: 1532-5768, accessed via Project Muse, July 1, 2011).

Elbourne, Elizabeth, 'The Sin of the Settler: The 1835-36 Select Committee on Aborigines and Debates over Virtue and Conquest in the Early Nineteenth-Century British White Settler Empire', Journal of Colonialism and Colonial History, 4/3 (2003) (E-ISSN: 1532-5768, accessed via Project Muse, October 31, 2011).

Elbourne, Elizabeth, 'Word Made Flesh: Christianity, Modernity, and Cultural Colonialism in the Work of Jean and John Comaroff, The American Historical Review 108/2 (2003): 435-59.

Etherington, Norman, 'Missionaries, Africans and the State in the Development of Education in Colonial Natal, 1836-1910', in Patricia Grimshaw and Andrew May (eds.), Missionaries, Indigenous Peoples and Cultural Exchange, (Brighton, Portland, Toronto: Sussex Academic Press, 2010), 123-37.

Etherington, Norman, 'Education and Medicine', in Norman Etheringon (ed.), Missions and Empire, (Oxford: Oxford University Press, 2005), 261-84.

Etherington, Norman, 'Introduction', in Norman Etheringon (ed.), Missions and Empire, (Oxford: Oxford University Press, 2005), 1-18.

Etherington, Norman, 'Missions and Empire', in R. Winks (ed.), Oxford History of the British Empire, Volume 5: Historiography, (Oxford: Oxford University Press, 1999), 303-14.

Evans, Julie, Grimshaw, Patricia, Phillips, David, and Swain, Shurlee, Equal Subjects, Unequal Rights: Indigenous Peoples in British Settler Colonies, 1830-1910 (Manchester: Manchester University Press, 2003).

Frykenberg, Robert Eric, 'Modern Education in South India, 1784-1854: Its Roots and Its Role as a Vehicle of Integration under Company Raj', The American Historical Review, 91/1 (1986): 37-65.

Garvey, Brian, 'Colonial Schooling and Missionary Evangelism: The Case of Roman Catholic Educational Initiatives in North-Eastern Zambia, 1895-1953', History of Education, 23/2 (1994): 195-206.

Goodman, Joyce, McCulloch, Gary, and Richardson, William, "Empires Overseas" and "Empires at Home”: Postcolonial and Transnational Perspectives on Social Change in the History of Education', Paedagogica Historica, 45/6 (2009): 695-706. 
Grant, John Webster, Moon of Wintertime. Missionaries and the Indians of Canada in Encounter since 1534 (Toronto, Buffalo \& London: University of Toronto Press, 1984).

Grimshaw, Patricia, and May, Andrew, 'Reappraisals of Mission History: An Introduction', in Patricia Grimshaw and Andrew May (eds.), Missionaries, Indigenous Peoples and Cultural Exchange, First Nations and the Colonial Encounter, (Brighton, Portland, Toronto: Sussex Academic Press, 2010), 1-9.

Hofmeyr, Isabel, 'Dreams, Documents and "Fetishes": African Christian Interpretations of "The Pilgrim's Progress", ', Journal of Religion in Africa, 32/4 (2002): 440-56.

Holmes, Brian, 'British Imperial Policy and the Mission Schools', in Brian Holmes (ed.), Educational Policy and the Mission Schools. Case Studies from the British Empire, 2nd edn. (London: Routledge \& Kegan Paul, 2007).

Holmes, Brian (ed.), Educational Policy and the Mission Schools. Case Studies from the British Empire, 2nd edn. (London: Routledge \& Kegan Paul, 2007).

Keshavjee, Rashida, 'The Elusive Access to Education for Muslim Women in Kenya from the Late Nineteenth Century to the "Winds of Change" in Africa (1890s to 1960s)', Paedagogica Historica, 46/1\&2 (2010): 99-115.

Kirkaldy, Alan, 'The Missionary Impact: The Northern Transvaal in the Late Nineteenth Century', History Compass, 7/3 (2009): 604-23.

Kriel, Lize, 'From Private Journal to Published Periodical', Book History, 11 (2008): 169-98.

Krige, Sue, " "Trustees and Agents of the State"? Missions and the Formation of Policy Towards African Education, 1910-1920', South African Historical Journal, 40 (1999): 74-94.

Lewis, Jane, 'Parents, Children, School Fees and the London School Board 1870 1890', History of Education, 11/4 (1982): 291-312.

Mackenzie, Clayton G., 'Demythologising the Missionaries: A Reassessment of the Functions and Relationships of Christian Missionary Education under Colonialism', Comparative Education, 29/1 (1993): 45-66.

Madeira, Ana Isabel, 'Portuguese, French and British Discourses on Colonial Education: Church \& State Relations, School Expansion and Missionary Competition in Africa, 1890-1930', Paedagogica Historica, 41/1\&2 (2005): 31-60.

Miller, James R., Shingwank's Vision: A History of Native Residential Schools (Toronto: University of Toronto Press, 2009).

Munro, Doug, and Thornley, Andrew, 'Pacific Islander Pastors and Missionaries: Some Historiographical and Analytical Issues', Pacific Studies 23/3/4 (2000): 1-31.

Novoa, Antonio, 'Empires Overseas and Empires at Home', Paedagogica Historica, 45/6 (2009): 817-21.

Nóvoa, António, 'On History, History of Education, and History of Colonial Education', Paedagogica Historica Supplementary Series, 1 (1995): 23-61.

Nóvoa, A., Depaepe, M., and Johanningmeier, E. V. (eds.), The Colonial Experience in Education: Historical Issues and Perspectives. Paedagogica Historica Supplementary Series, vol. 1, (Ghent: C.H.S.P., 1995).

O'Brien, Anne, 'Creating the Aboriginal Pauper: Missionary Ideas in Early 19th Century Australia', Social Sciences \& Missions, 21/1 (2008): 6-30.

Pakendorf, Gunther, 'A Brief History of the Berlin Mission Society in South Africa', History Compass, 9/2 (2011): 106-18.

Porter, Andrew, Religion Versus Empire?: British Protestant Missionaries and Overseas Expansion, 1700-1914 (Manchester: Manchester University Press, 2004).

Prochner, Larry, May, Helen, and Kaur, Baljit, “ “The Blessings of Civilisation”: Nineteenth-Century Missionary Infant Schools for Young Native Children in Three Colonial Settings - India, Canada and New Zealand 1820s1840s', Paedagogica Historica, 45/1\&2 (2009): 83-102.

Ranger, Terence, 'African Attempts to Control Education in East and Central Africa 1900-1939', Past E Present, 32 (1965): 57-85.

Rooke, Patricia T., 'A Scramble for Souls: The Impact of the Negro Education Grant on Evangelical Missionaries in the British West Indies', History of Education Quarterly 21/4 (1981): 429-47.

Ruberu, Ranjit, 'Missionary Education in Ceylon', in Brian Holmes (ed.), Educational Policy and the Mission Schools. Case Studies from the British Empire, 2nd. edn.(London \& New York: Routledge and Kegan Paul, 2007), 73-114.

Seth, Sanjay, Subject Lessons. The Western Education of Colonial India (Durham and London: Duke University Press, 2007).

Sivonen, Seppo, White-Collar or Hoe Handle? African Education under British Colonial Policy 1920-1945 (Helsinki: Suomen Historiallinen Seura, 1995).

Stanley, Brian, The Bible and the Flag. Protestant Missions and British Imperialism in the Nineteenth and Twentieth Centuries (Leicester: Apollos, 1992).

Strayer, Robert W., 'The Making of Mission Schools in Kenya: A Microcosmic Perspective', Comparative Education Review, 17/3 (1973): 313-30.

Taylor, W. H., 'Missionary Education in Africa Reconsidered: The Presbyterian Educational Impact in Eastern Nigeria 1846-1974', African Affairs, 83/331 (1984): 189-205.

Turner, Mary, and Slaves, Missionaries. The Disintegration of Jamaican Slave Society, 1787-1834 (Urbana, Chicago, London: University of Illinois Press, 1982). 
Urch, George E., 'Education and Colonialism in Kenya', History of Education Quarterly, 11/3 (1971): $249-64$.

Watson-Gegeo, Karen Ann, and Welchman Gegeo, David. 'Schooling, Knowledge, and Power: Social Transformation in the Solomon Islands', Anthropology \& Education Quarterly, 23/1 (1992): 10-29.

Whitehead, Clive, 'The Concept of British Education Policy in the Colonies 1850-1960', Journal of Educational Administration \& History, 39/2 (2007): 161-73.

Whitehead, Clive, 'Education in British Colonial Dependencies, 1919-39: A Re-Appraisal', Comparative Education, 17/1 (1981): 71-80.

Whitehead, Clive, 'The Historiography of British Imperial Education Policy, Part I: India', History of Education, 34/3 (2005): 315-29.

Wilson, J. Donald, "No Blanket to Be Worn in School": The Education of Indians in Nineteenth-Century Ontario', in Jean Barman, Yvonne Hébert and Don McCaskill (eds.), Indian Education in Canada, (Vancouver: University of British Columbia Press, 1986), 64-87.

Woodberry, Robert, The Shadow of Empire: Christian Missions, Colonial Policy, and Democracy in Postcolonial Societies, Ph.D. dissertation (University of North Carolina at Chapel Hill, 2004).

Yates, Barbara A., 'African Reactions to Education: The Congolese Case', Comparative Education Review, 15/2 (1971): 158-71. 